\title{
Evolution or Revolution?
}

A review of Chris Knight's Blood Relations: Menstruation and the origins of culture. London \& New Haven: Yale University Press, 1991.

Timothy Mason, Université de Paris 8 2000.

The first academic anthropologists were much influenced by Darwin. The ways in which Tylor or Frazer applied the selectionist theory of evolution have often been summarily characterized as an Imperialistic and ethnocentric form of Social Darwinism, but in fact their thinking was more interesting and more complex than that. Nevertheless, when a new generation of anthropologists, closer to the terrain, less interested in historical questions, took over the baton, they renounced the search for the Key to All Mysteries, leaving Frazer to the poets and novelists. For Malinowski and Radcliffe-Brown, the Savage ceases to be the witness to our prehistoric past, and becomes a man like others, his daily cares and fundamental needs being much like our own.

The anthropological community congratulated itself on having turned its back on Big Questions without answers. New, more properly scientific problems could now be tackled with new, more properly scientific methods. But, perhaps unfortunately, it may be that the social sciences are open to other pressures, other criteria, than are the hard sciences. Malinowski owed his success with the public to the tales and anecdotes that run through his work ; his theoretical contributions have never fully satisfied the specialists. However, in general, after the anthropologists abandoned their early attempts to outline a history of humankind, they found little favour with the ordinary reader. If some of their works still attracted attention, these were more likely to be moral tales of the kind that Colin Turnbull offered in his books on the M'Buti, whom he found in a state of grace, or on the lk whom he saw as prefiguring our own terrifying future. As Chris Knight remarks, by renouncing the quest for origins, the anthropological community lost its readers and cut itself off from contact with the world at large.

The vacuum, argues Knight, was quickly to be filled by sociobiology, first launched by Edward O. Wilson, but then taken up, above all, by the primatologists working in the wake of De Vore and Goodall. The chimpanzees of Gombe or the baboons of 'The Pumphouse Gang' filled our Sunday colour supplements. So powerful were the stories told, that sometimes it was as if human beings were nothing but apes with language added on ; culture came to seem nothing more than a kind of varnish behind which one might espy the naked ape, armed with reproductive strategies and engaging in power struggles which were the very image of those of our primate cousins.

A fully evolutionist theory of culture had to await the publication of Richard Dawkins' book 'The Selfish Gene'. At the centre of this theory is the 'meme', which plays the same role of 'replicator' as the gene fills in biological evolution. And just as in the biological world, memes must obey combinatory rules. Thus our history can be characterized as a struggle between memes for their survival, and the elaboration of structures which are more and more complex, but which follow a few basic principles. This thesis is more seductive for the humanist than are the constructs of the sociobiologists, for it points to a radical cut-off between biology and culture. Memes are the new replicators, the wave of the future, which means that humanity is to be at the centre of the new programme. Furthermore, the literary critic will recognize a familiar air, for 'memology' offers echoes of the work the Russian 
formalists, of Vladimir Propp's analyses of folk-tales, or of Lévi-Strauss's work on mythologies.

\section{Blood Relations; a Marxist sociobiology}

It is in this context that Chris Knight's book may be read. Knight is a theoretician rather than an ethnologist, and his writings are based on the observations made by others; the shadows of Frazer, Freud and Lévi-Strauss lie across his pages. A militant socialist in the tradition of Engels, he sees his work as a left-wing response to sociobiology, which he characterizes as the Political Economy of our time. It is, he believes, up to Marxists to use and transform it. But he is a resolutely post-modern Marxist; one of the names he invokes - along with that of Mary Douglas - is Donna Haraway, for he has drawn much of his inspiration from her 'Primate Visions'. Knight tells us that he will add his own story to the others, that it will be a resolutely political story, with no pretensions to objectivity.

The tale that he unfolds is, predictably, one of revolution - the fundamental revolution, centred on reproduction and sexuality. It is not, he assures us, true to say that human nature is such that revolution is impossible to accomplish - on the contrary, our humanity, our cultures, our relational networks come into being through and in a revolution initiated by women 100,000 years ago, and through the counter-revolution subsequently mounted by men. Thus it was that our humanity was forged by women, whose fundamental needs for food and for help in raising children form the foundations upon which culture was to be erected.

Let us follow one of his key illustrations: the Sharanahua is a South American people among whom one may regularly see a group of young women, arrayed in their finest garments and very visibly painted, form a line, dance together, and challenge the young men. Each of the women chooses a man whom she orders to go off into the forest and hunt for her. Off go the men; when they return, the women are waiting for them. Unhappy is the wretch who comes back empty-handed; he will do his best to creep into the village unperceived, and to hide in his hut. The lucky hunter, however, lays his prey down at the entry to the village, where the women are waiting, and goes off to prepare himself for the festivities. He knows that he will that very night enjoy the favours of the woman by whom he was chosen.

Knight tells us that this scenario is a distant echo of the birth of all human culture. Women need men - not as mere genitors, but as providers of goods and services. To persuade males to play a role so rare among primates, women have recourse to a 'sex-strike'. Knight sums this up in the formula: No meat, no sex. To underpin his theory, he follows two paths; first he carries out a rewrite of Lévi-Strauss, and second he tries to show how the very specific physiology of the human female can be explained by the 'sex-strike'. To this anthropological theory, Knight adds in counter-point an account of his own development. Throughout his book, he reveals how his own intellectual and political evolution influenced his scientific choices. The chapters of his book do not simply follow an argumentative chain, tracing out the logical steps in the construction of his theory; they also trace out the pathways which lead from the youthful naivete of the early militant to the mature adult capable of making an honourable contribution to the revolutionary project.

\section{Incest and 'own-kill'}

Lévi-Strauss places the birth of culture under the sign of the incest-taboo. But, argues Knight, that does not go far enough ; women are not just pawns in a game played out between groups of brothers. On the contrary, they are themselves the main players. The incest taboo cannot be understood unless it is placed in the context of a second taboo, the 
traces of which, he says, are to be found in virtually all hunter-gatherer societies : a hunter is forbidden to consume the meat of an animal that he has killed himself. This is what Knight calls 'the own-kill rule'. In most cases, the hunter must offer the meat to one or another of his in-laws. Often enough, he must provide his wife's family with meat and other services for years before he is admitted as a son-in-law. To taste the blood of an animal that one has brought down oneself is the equivalent of an incest - you should not sully your own blood. Knight writes:

"If one's 'taboo' or 'totem' is not one's 'meat' or 'blood' or 'flesh' in the most literal sense, it is at least one's 'spirit', 'substance' or 'essence'. And the crucial point is that the 'self', however conceived, is not to be appropriated by the self. It is for others to enjoy. According to this logic, a man's sisters are inseparable from himself, and, sexually, they are therefore for others to take as sexual partners. A man's hunting products - the game animals which he kills - are likewise inseparable from himself, and are his own flesh, his own blood, or his own essence which he is not allowed to eat. Not two rules are in force, but only one; the rule against 'eating one's own flesh'."

Upon this basis is erected a cycle which lasts one lunar cycle. During the period of the new moon, women remain among their families of origin - the group of sisters, of mothers and of children, often living together under the same roof. The men, for their part, go out to hunt. During the period of the full moon, the women join their husbands or their lovers - if they have succeeded in bringing meat back to the village. The men, as we can see, sexually consume blood which is not their own. And the women, their sisters, their mothers, their children and their brothers, eating the meat which has been brought by their lovers, also consume blood which is not their own.

It has to be said that in his critique and extension of Lévi-Strauss, Knight offers arguments which are pertinent and interesting, and that the quasi-symmetrical structure which he establishes from the different forms of taboo is pretty convincing. But Knight wants to go further than this; like Freud, whom he invokes, he is in the business of digging up a primary scene - the sex-strike. In the natural world, as we may learn from the writings of the primatologists, society is pretty much a collection of individuals, each of which has its own personal interests. Whether eating or reproducing, in the end, each individual is in it for him or herself. Some kind of rudimentary alliance can arise, but there is no true exchange monkeys do not exchange food, do not exchange sexual partners, unless they are threatened by a stronger individual. Human beings, as Lévi-Strauss understood, can do this.

The question that must be asked, claims Knight, is how women managed to escape from the control of the dominant males, and how they managed to persuade the other males to work for them, to free them from the need to spend all their time looking for food to the detriment of their maternal roles. This is indeed a critical question, for human babies are even more fragile than are monkey infants, of which many die while very small due to accidents occasioned by the mother's need to be mobile in order to feed herself. Human females, then, have a strong interest in establishing a home base or semi-permanent camp, and in getting men to do the work of provisioning.

This brings us to a crucial point in the argument; Knight illustrates it by reference to another, altogether different species. Among sea-horses, monogamy is the rule. The females impose this form of sexual relationship through the synchronization of their ovulation - all the females produce their eggs at exactly the same time and so the males cannot easily fertilize a number of females. Female sea-horses use the moon as a cosmic clock. Human females, suggests Knight, did the same thing. 
A group of women began to ovulate in synchrony, producing their eggs at the time of the full moon. Their menstruation, obviously, was also collective, and coincided with the new moon. The women's sex-strike occurs, then, at the moment of the new moon, and is realized through collective menstruation. Let us see how the strike could have been put in place.

\section{Women, periods and the moon}

Human sexuality is rather different from that of our closest relatives, in particular as it concerns the females of the species, for whom the most marked characteristics are the absence of estrus and permanent receptivity. Although there are primate species with similar characteristics - particularly those which are monogamous - it is not usual and never as strongly pronounced. One explanation, put forward by Desmond Morris, among others, is that the female attempts to capture her mate's long-term attention through offering a greater intensity and continuity of sexual pleasure. It has also been pointed out that the absence of estrus means that if a man wants to be sure of impregnating his partner, he must maintain sexual relations with her over a longer period than is the case among chimpanzees.

Knight remains unconvinced by all this. What is marked among the females of our species, he argues, is not her constant receptivity, but rather the moment when she is less receptive her menstrual period. He writes:

"Despite oestrus loss, hormonally controlled sexual signals are not entirely missing from the human female menstrual cycle. On the contrary, menstruation in the human case has been accentuated as an external display. It is at menstruation rather than ovulation that the human female experiences her behaviour as hormonally influenced to a certain degree."

And he adds :

"A woman loses considerably more blood during menstruation than does any other primate. This shedding of blood, although small, represents a significant loss - a loss which has to be made good by additional food intake, particularly of iron. The adaptive advantage of this has not yet been explained".

Menstruation, he suggests, functions as a signal. It lets men know that the woman will refuse sexual intimacy. But this is not enough ; all fecundable women must signal their refusal at the same time. Knight needs to demonstrate that this is possible. He begins by noting that although the menstrual cycle is not necessarily linked to the phases of the moon - periodicity among primates is variable - the typical cycle of the human female lasts 28.5 days, and coincides exactly with the lunar cycle. Next, Knight cites the results of some research that indicates that when women spend enough time together - in a boarding school, for example, or a university dormitory - they tend to have their periods at the same time.

Women, then, are capable of menstrual solidarity, and of clearly demonstrating, all together, that they are not disposed to have sexual relations. They use the moon and the tides to synchronize ; at the new moon, women have their periods. They remain shut away in their homes. They mock the men, as Sharanahua women still do today : "There's no meat in the house", they say, "we'll eat penises". The men, thus reminded of their human duties - duties of exchange and reciprocity - get together to organize the hunt. They will return, says Knight, around the full moon, loaded with meat.

\section{Women, men and culture}


At first, the occasional sex-strike did not bring about a radical break between nature and culture. This only came about when our ancestors were forced to quit the coastal regions under the pressure of the new meteorological conditions brought about by the last lce-Age. Knight situates the break very late, putting it at only 70,000 years ago. It was at this period that, deprived of the resources of the sea such as fish, crustaceans and baby seals, women began to feel the need to force men to go hunting regularly.

This required an elaborate social organization; one the one side, the women, who had to plan and put into effect the strike, and on the other the men, who had to plan and carry out the collective hunt. For the women, menstrual blood linked to menstrual synchronization was the basis of their solidarity. But at any one time, only a minority of women would be having regular periods: pregnant women, those with unweaned children, older women and the undernourished do not bleed. Even today, among hunter-gatherers, menstruation is rare, and very few women have the regular cycles that their counterparts in industrial societies undergo - indeed, anthropologists refer to this rarity of periods when they try to explain why such peoples hold menstrual blood in abhorrence. So there is not enough real blood to do the trick - particularly if the hunt lasts for several days, and the men who have remained at the home base must be kept at bay. Knight at this point in his argument brings in the fact that a good number of archeological sites show quite abundant traces of red ochre :

"... it is reasonable to suppose that on many occasions, humans would have experienced the need to make visible the source of the 'magic'. The strike itself may have seemed in this context somewhat demanding of blood. If my hypothesis were correct, we might expect to find cultures to have evolved artifices serving to amplify the visual impact of women's blood. Real menstrual blood dries, flakes and turns almost black rather than red within a few hours. If women wanted to declare themselves defiantly 'powerful' for longer and longer periods, and wanted to express this in some visually unmistakable way, they may well have felt the need to augment their blood with something which stayed red for longer and did not quickly flake. Could red juices, ochre, or mixtures of ochre with blood and/or animal fat, have fulfilled such a function?"

Understandably, Knight replies to his own question in the affirmative. Symbolic culture, according to this hypothesis, comes to light in the body-decoration of women. The first human message is that addressed to the male group by the female group who, covered in red, the emblem of their menstrual blood, say a collective 'No', and offer the first exchange. Sex, says Knight, for meat.

This is the source of two fundamental taboos: the women remain in the base camp, and with them are the children and the young males who are too young to hunt, old people, and a few males who are left behind to protect the group. The men who go on the hunt must be sure that the women will not lie with the men who stay behind: sons and nephews become taboo. At the same time, the men must promise not to keep the meat for themselves, and in this way, the own-kill taboo is put in place.

\section{What kind of feminism?}

Knight sees his work as contributing to those currents in anthropology and sociobiology which take account of the feminist perspective - but not just any feminist perspective:

"Influenced by friends and comrades who were feminists, I naturally felt feminism of any variety to be a liberating political force. But ... for the women I was closest to (many of whom were involved in the Greenham Common anti-Cruise missile 
campaigns of the early 1980s), the construction of 'female males' was not what the struggle was all about, any more than joining the capitalists was the essence of working-class emancipation. The struggle was more about refusing to collaborate with the whole masculinist political set-up, organising autonomously as women, drawing on support for real change from the wider class struggle - and fighting to bring men as allies into a world transformed on women's terms."

It may be - at least in part - for this reason that Knight takes such pains to reject the idea that the exchange offered by the women could be seen as a form of prostitution. He insists that among hunter-gatherers, it would be immoral in a woman to offer sex without demanding a gift in return, rather than in insisting on payment. In South America, in Melanesia, in Africa, the woman always expects the lover or husband to offer her gifts each time she makes love to him. The prostitute, says Knight, is not she who insists on the strict application of the basic rules imposed by the sex-strike. On the contrary, it is the strike-breaker, who offers her body to men on demand - by thus undermining feminine solidarity, she threatens society itself. Prostitution does not consist in the simple demand of a reward for sexual services, but in undercutting the trade-union price and offering up one's body in the place of other women. The woman who openly demands a gift makes the rules clear; the prostitute muddies them.

How is it, then, that the prostitute is present in almost all human societies, and is so common in modern societies? According to Knight, she will only proliferate in societies which are dominated by men, in patriarchal societies. How is it, then, that if women gave birth to culture, women in all cultures find themselves under the masculine thumb?

Knight's reply to this is that after the revolution, there was a counter-revolution. This counterrevolution is clearly recognized and celebrated by men. To demonstrate this, he takes the case of Australian Aboriginal peoples, among whom the myth of the Rainbow Snake is widely disseminated. This serpent, which swallows menstruating women, and which brings members of the same blood line together, where they should remain separate, is the very symbol of feminine solidarity, founded on the sex-strike and on synchronized menstruation, says Knight. But, in Aboriginal mythology, it can be seen that the men have hijacked the snake, putting themselves in the place of the women at the moment of collective menstruation. Women, they say, do not have 'real periods' - which is why they must be socially isolated when they bleed. Kept apart from one another while they menstruate, women are no longer able to synchronize, are not longer able to announce and celebrate the strike. Men, on the other hand, through sub-incision or other forms of self-mutilation, practiced collectively, particularly during rites of initiation, substitute themselves for women, taking their place as the guarantors of the social system. Knight cites one of the male participants in these rites:

"But really we have been stealing what belongs to them (the women), for it is mostly all woman's business; and since it concerns them it belongs to them. Men have nothing to do really, except copulate, it belongs to the women. All that belonging to those Wauwalak, the baby, the blood, the yelling, the dancing, all that concerns the women; but every time we have to trick them. Women can't see what men are doing, although it really is their own business, but we can see their side. This is because all the Dreaming business came out of women - everything; only men take 'picture' for that Julunggul [i.e. men make an artificial reproduction of the Snake]. In the beginning we had nothing because men had been doing nothing ; we took these things from women."

According to Knight, the Aborigines have maintained in their myths and ritual practices the memory trace of a critical moment in the evolution of culture - the moment when men 
overthrew the existing order and imposed masculine domination. This could only occur through a revolution in symbolic representations. The Snake would no longer swallow women.

\section{The primal scene?}

Knight knows that the story he tells is but one among many. But, he claims, his is a special kind of story, for though it is indeed a myth, it is a scientific myth. He believes that science must be liberating. His story, he says, may aid progressive forces in their struggle against the dominant ideology, and help give them back the confidence that they have lost since the $70 \mathrm{~s}$, to dream once more of revolution. In an England where the Left is in disarray, where the Labour Party is in the hands of an admirer of Mrs. Thatcher, one may understand why Knight - who cites Ken Livingstone in his list of acknowledgments - wants to find new foundations upon which to construct a radical critique of society. But at what price? In order to construct his myth, Knight is forced into simplification and abstraction from the cultural whole. Thus, he says at one point that for the populations from which our species sprang there is a moment when blood is only blood and all blood is alike. However, it is known that in hunter-gatherer societies, blood can only be understood in its relationship to other bodily fluids - milk, sperm and bile. And it is also the case that blood is multiple. But this complexity would put a brake upon the sociobiological imagination, just as the recognition of similar inter-relationships put a brake on the project of Taylor and Frazer. Perhaps that is why Knight - with much precaution - is willing to accept the concept of 'meme'. As he says :

"I intend to draw on this parallel between 'genes' and 'memes' not because I find the analogies convincing ... but because this way of looking at matters helps to validate my own narrative of a 'human revolution' which transported evolution beyond the parameters of ordinary Darwinism."

Memology allows cultural elements to be abstracted from their contexts, and permits the identification within a rite or social practice of forms or formulas that are susceptible to being thus abstracted. But one of the problems of this approach is that it is always tempting to do nothing other than to project upon our distant past the configurations of our own desires. Knight sees the trap:

"Although I scarcely understood its scientific complexities, sociobiology by this stage did not simply repel me, despite its obvious political roots. Indeed, I warmed to its ideological excesses. They seemed to promise for the first time a publicly communicable way of validating my own narrative. If the stockbrokers, the company directors and the bourgeois feminists could be uninhibited about projecting their purely political constructs into primatological and palaeoanthropological debate - then how could they object to a socialist doing the same? Obviously, it seemed to me, they could not object in principle. The bone of contention could only be the extent to which - if at all - our respective grids worked."

He admits, then, to projecting onto the canvas that he has imagined his own political values and hopes. But it is possible that other, less well-controlled material, has also made its way into the picture. At the centre of his myth, we find the moment of revolution itself. We have already caught a glimpse of what we may justifiably refer to as the 'primal scene' in the dance of the Sharanahua women. But how did the first fully human females put their revolt into practice?

"Let us return to the imagined protohuman population still only tentatively pursuing the new strategy. Genetically this population would be heterogeneous, with some 
females more desirable in male eyes - and more interested in sex - than others ... In reality, the whole purpose of female strike action would have been not to avoid sex altogether, but to make males go away only temporarily - and then to come back home with meat. Not only does this assume that males are motivated to return to females. It also implies that females can enjoy sex sufficiently to have something to offer when the males do return ... Because of this, the new system could have worked only on the reverse basis, with those females most wanted by males being among the first to get organised."

At the very centre of our cultural revolution, then, we find the most voluptuous women. Knight goes on:

"Given the logic just outlined, females set on following the new strategy would clearly have done best if they could (a) arouse the sexual motivations of males prior to each hunting exhibition whilst (b) making absolutely sure that no actual sex - no consummation or fulfilment - was allowed. The need, then, would have been to find a balance, sharpening the edge of the strike weapon not by disclaiming all sexual interests - but rather by dangling before the hunters' eyes the rewards in store for them once their tasks had been performed."

Here it is that we find the origins of clothing. Quoting Lystistrata's oath ("I will live at home without any sexual activity, wearing my best make-up and my most seductive dresses, to inflame my husband's ardour"), he writes :

"Bangles, beads, necklaces and other adornments, many in the form of pierced marine shells, appear suddenly in the archaeological record in great abundance during the very earliest stages of the Upper Paleolithic. Doubtless, they were accompanied by pigments, pubic coverings, shawls, tassels and other items of ornamental clothing made of materials which have unfortunately not survived. Taken together - and leaving aside the possible physical functions such as protection or warmth - these items would have conveyed symbolic information on various levels. Firstly, they would have helped combine bodily concealment with allurement. We can imagine women deliberately dressing up - and very probably also dressing one another up - in order to mark the start of each 'strike'."

Knight sees a (fairly reduced) role for the older women, but at the centre of his vision we find the young women and the young men. Mature men, children - and one may imagine that in the emergence of humanity, the relationship between mother and child will have been of some importance - are thrust to one side. This is exactly what we see in the dance of the Sharanahua of which he makes so much, and in which only the young are involved. But while the rites that surround the sexuality and the alliance of the young are often of great importance in human societies, it is very rare for these questions to be left to the entire discretion of the adolescents themselves. We may wonder whether Knight has not - at the very centre of his construction - allowed memic simplification to reduce the play of culture to a sort of night-club for teenagers.

\section{Conclusion}

The philosopher Mary Midgely has said that evolution is our Creation Myth, and that we could characterize it as a religion. Scientists like Crick or Wilson base upon it their projections of a radiant future when scientists, finally getting rid of ordinary human beings, will be free to shape the world as they wish. Knight does not share their elitism - as we have seen he believes that his enterprise is a leftist response to the conservatism which he 
detects within sociobiology. But, similar in this to his adversaries, he has a teleological conception of evolution. Thus it is that, from time to time, one may detect a note of irritation towards our ancestors - why did it take them so long to invent culture? But while Kipling, in imagining the origins of the alphabet, projects the bourgeois family back into our prehistory, Knight sends the striker, the feminist, and the political militant back into the past.

Has he succeeded? If by that you mean has he made a contribution to the debates within the domain in which he situates his work, one may say that he has met with some recognition; Blood Relations has been read and commented on by palaeoanthropologists and sociobiologists - and a certain number of young researchers such as Camilla Power have signed themselves on board. Knight himself, as a militant socialist, has published articles intended to popularize his ideas in left-wing journals. Even if he has not gained the popular audience that Engels or Morgan achieved with their versions of evolutionary theory at the end of the 19th Century, he may imagine with some confidence that his works will be read in some working-class homes. Knight has also contributed to bringing about a renaissance of evolutionary cultural theory within academic anthropology - although he was not by any means on his own here. To some extent, he has benefited from the swing of the pendulum; a generation of anthropologists who read Ardrey or Lorenz in their youth has joined the few voices - like that of Robin Fox - which have steadily rejected the idea that culture is an autonomous domain, ultimately inexplicable, as Boaz had characterized it. But he has also contributed to it; it was under his impulsion that the colloquium 'Ritual and the Origins of Culture', held at the School of Oriental and African studies was held in 1994, and gave rise to an edited volume bringing together the work of psychologists, anthropologists and historians in an attempt to outline the biological origins of rites, and their place in the evolution of our species.

Problems remain: some paleoanthropologists still believe that traces of culture can be found among the Neanderthals - for Knight, it is important to argue that the latter were displaced by modern humans because they did not possess culture. And one may also add that Knight's myth can only hold if one ignores the contributions to culture that must have been made by the long and intimate relationships between mother and child, between brothers and sisters - among chimpanzees, where infants remain attached to their mothers for a long time, social placement and a rough version of lineage can be seen.

But to conclude, we shall need to leave the field that Knight claims as his own. Well before he studied anthropology, Knight did an MPhil in Russian Literature at Sussex University. His first culture is literary - as one might expect, he cites Robert Graves, he quotes Propp, and he has read Girard. As a story-teller, he is not naive. He knows that he is offering at the same time a myth, a scientific theory and an autobiographical novel. It is a Dickensian story 'Great Expectations', perhaps - that of a young man who seeks to make his way in a world both threatening and exciting, a young man who catches a glimpse of the love of his life in the light of a palaeolithic camp-fire, who loses sight of her in his quest for the truth of the world and the authenticity of his soul, but who nevertheless keeps his flame alight, hoping to find her again in a better world towards the forging of which he will himself have contributed. Knight's hero is worthy of love, for as a true Romantic lover, he has long laboured at the construction of his beloved.

Is it because he inserts himself into the story he tells, because he continually lets the reader know that he himself is not duped by the tale, that he manages at least to suggest that, while he may not completely convince, he does offer a way out of the present impasse?

Sociobiology, even when practiced by those who are not inveterate conservatives - and not all of its adepts are - has trouble doing much other than to sing to what is - or at least to what they imagine is inscribed in our genes. Memology, in its turn, submits us to the tyranny of 
ideas or of rites - Dawkins, for example, sees religion as a kind of virus against which ordinary men have little defence. Knight offers us a model of the birth of culture which, born in practices and needs which are firmly rooted in our biological nature, nevertheless takes form in the real will of our ancestors to impose a collective and liberatory solution to a common problem.

\section{Bibliography}

Dawkins, Richard, The Blind Watchmaker, Penguin, London \& New York, 1986.

Dunbar, Robin, Chris Knight \& Camilla Power (eds.), The Evolution of Culture, Edinburgh University Press, Edinburgh, 1999.

Frazer, James, The Golden Bough: A Study in Magic \& Religion, (Abridged Edition), Papermac, London, 1987.

Haraway, Donna, Primate Visions: Gender, Race \& Nature in the World of Modern Science. Routledge, New York \& London, 1989.

Knight, Chris, Blood Relations: Menstruation and the Origins of Culture, Yale University Press, New Haven \& London, 1991.

Knight, Chris, Sex and Language as Pretend Play, in Dunbar, Knight \& Power, 1999, pp. 228-247.

Midgely, Mary, Evolution as Religion: A Comparison of Prophecies, Zygon, vol. 22, No. 2 (June 1987), pp. 179-194. 10 